\title{
The Mediterranean Model in European Economic Thought
}

\author{
By Catia Eliana Gentilucci*
}

\begin{abstract}
The Mediterranean Economic Model (MEM) is understood as being a system of thought involving Greece, Italy and Spain which places man at the centre of economic relations, unlike other economic models which are based on the individualistic approach and see man as a rational, passive product determined by economic processes. MEM is part of the more general European Social Model, in which three distinct approaches to capitalism based on different religious and historical backgrounds can be observed: the social market economy, inspired by Lutheranism; the Mediterranean Economic Model, inspired by Catholicism, has its roots in Aristotelian thought and, through the contribution of Thomas Aquinas, reaches Spain; and a more traditional approach, the Anglo-Saxon (neoclassical mainstream), is inspired by Calvinism and Lutheranism. This paper maintains that, due to their different cultural approaches to welfare, MEM countries are struggling with economic growth. In reality, the evident difference between Mediterranean and continental Europe regarding the management of public spending ought to make us reflect on the fact that historical processes should never be underestimated.
\end{abstract}

Keywords: European Social Model, Lutheran and Catholic Capitalism, Welfare Society.

\section{Introduction}

The Mediterranean Economic Model is understood as being a system of thought involving Greece, Italy and Spain which places man at the centre of economic relations, thus transcending the individualistic economic approach.

The philosophy of MEM reverses the relationship between the individual and the market: man is not seen as being at the mercy of market rules; on the contrary, man is an active subject towards whom the market has obligations such as guaranteeing employment opportunities for everyone according to their abilities and aptitudes as well as an adequate level of social well-being (education, health and safety), all the while respecting the underlying principles of fundamental human rights.

In this view, it is not the individual who suffers the consequences of free market actions, but the system of economic relations which should focus on obtaining results which are effective and efficient for the general well-being of the community.

MEM governments have in common the fact that their economic policies aim to maintain adequate levels of growth at the same time as decent working conditions and welfare opportunities.

\footnotetext{
"Researcher in History of Economic Thought, University of Camerino, Italy.
} 
MEM is part of the more general European Social Model in which three distinct approaches to capitalism based on different backgrounds can be observed (Gosta Esping 1990).

Though aware of the fact that these approaches are influenced by the culture, history and traditions belonging to each country, in this work our focus will be mainly on the religious aspect as we believe this is particularly relevant in forming the civic conscience that characterises individual civilisations.

Thus, in this paper we maintain that: the social market economy, inspired by Lutheranism, favours the adoption of a restrictive economic policy and a government that, due to its focus on monetary stability, endorses the free market; the Mediterranean Economic Model, inspired by Catholicism, has its roots in Aristotelian thought and, through the contribution of Thomas Aquinas, reaches Spain. Far more attentive to social well-being and the conditions of workers, this approach proposes a return to Keynesian policies in order to support demand; finally, a more traditional approach is the Anglo-Saxon (neoclassical mainstream), inspired by Calvinism and Lutheranism. Here, it is the duty of the market to recognise when the system is in balance, resorting to demand and supply side economics to tackle unequal distribution (keeping the Phillips Curve in mind).

In order to achieve economic growth, these models employ widely different instruments and prioritise different economic policies. Unsurprisingly, they are based on value systems that developed from diverse socio-cultural traditions (Fortis and Quadrio Curzio 2007).

In particular, MEM draws inspiration from the Keynesian model of welfare society; the SME sees the welfare state as protective of a monetarist free market; the Anglo-Saxon model is slightly more flexible in choosing appropriate policies.

This paper maintains that, due to their different cultural approaches to welfare, MEM countries are struggling with economic growth, bound by restrictive policies imposed by the current European mainstream which can be seen in the restrictive ESM monetary policies responsible for shaping European economic thought.

\section{Europe, between History and Religion}

In the Europe of today, it is possible to detect two distinct models of Capitalism: one, based on Lutheran values, is rational and pursues the efficiency of economic aims. Here, the only institution able to guarantee the existence of a free market is the state; the second, inspired by Franciscan-Catholic values, prioritizes social interests and aims for economic efficacy. In this model, civil society is conceived as an organisation acting between market and State to benefit the common good.

On the contrary, in the British tradition the emphasis was on hard work, rather than enjoying the fruits of one's labours. In fact, hard labour was not just seen as a positive undertaking but was actually included in the system as a good, while Catholicism and the countries it influenced took a more lenient view of consumerism, recognised as being one of the forces which improve the production process. 
In this sense, Latouche's essay, Minerva's Challenge (2000, 62), separates the 'reasonable' from the 'rational'. The reasonable is seen as the wisdom of economic behaviour based on the efficacy of the desired result, that is to say on its economic and social impact (the number of individuals who ultimately benefit from results). The rational, instead, represents the a-valorial economic logic of the efficiency of economic results (with no reference to ethical values) (Gentilucci 2018).

The concept of 'reasonable' is based on the Aristotelian tradition in which systematic observation was directed to investigating the world and ultimately spawned a theory of reasoning which is known to us as natural law.

\section{The Historical Roots of the Mediterranean Economic Model}

This model can be observed in the countries of Southern Europe (Italy, Portugal, Greece and Spain) and is set apart by a view of capitalism inspired by a philosophical paradigm based on the reflections of Aristotle (Greece), Thomas Aquinas and St. Francis of Assisi (Italy) and the School of Salamanca (Spain) ${ }^{1}$.

Mediterranean Europe is at the crossroads of humanism and Christianity, between Catholicism and Islam. The European experience is characterised by the growth of religious sentiment as a part of symbolic orientation in the quest to reclaim a personal sense of identity. The crisis of faith of the last twenty years has fundamentally altered our relationship with the divine, shifting the search for social identity from a life lived in accordance with religious beliefs towards a search for new forms of spirituality which are heavy with political implications.

The evocative, emulative nature of transcendental individual experience has become a search for increasingly secular socio-cultural values which are capable of bringing meaning to the choices of daily life. The Catholic church has become more secular, the bastion of the democratisation of society.

Though Spain is not a stranger to this trend, in Italy it goes hand in hand with the emergence of political parties, associations and movements which are inspired by Catholic principles. A separate discussion is reserved for Greece, as the profound common sentiment of national identity and faith to a political power in orthodox religion does not translate into identifying with a political party, as is commonly found in Italy (Vryonis 1978) ${ }^{2}$.

The philosophical matrix of MEM derives from Thomistic personalism, a stance that emphasizes the importance of good over fairness. This concept had already been taught by Aristotle, who spoke of the 'common good' which is achieved by putting aside personal interests. In his words, if each man were to follow his own individual will, the government of the lives of men would be destroyed.

\footnotetext{
${ }^{1}$ Rothbard (1995).

${ }^{2}$ To this day, Greece is one of the European countries where membership in the orthodox Christian faith is most deeply felt, as explained in a 2017 Pew Research Institute report. Under art.3 the Greek Constitution defines orthodox Christianity as "the prevailing religion in Greece"; furthermore, the second section of this norm defines the relationship between Church and State. A relationship which is nonetheless characterised by mutual respect and independence.
} 
Instead, the theoretical approach to MEM economies can be summed up in the Civil Economy approach.

After all, during the age of Scholasticism, economics (considered as a science) was one of the subjects which were studied by the pagan philosophers and moralists such as Aristotle in Greece, who discussed the role of economics in four of his works: The Topics, Rhetoric, Nicomachean Ethics and Politics.

In the course of the XIII century, medieval Christian philosophy (Thomist scholasticism) achieved its highest expression through the meeting of Christian belief and Greek philosophy. Thomas Aquinas had the amazing ability of placing principles acquired from the study of Aristotle and the principles of Christianity within a framework that was both theological and philosophical, and this was to become the basis for Mediterranean Thomistic economic theory (Woods 2005).

In his Nicomachean Ethics, Aristotle anticipates Bentham's more modern form of utilitarianism by affirming that for mankind the real good is happiness, understood as being "what we count as self-sufficient is what renders life in need of nothing". Again, in Aristotle's view, happiness consists in the "activity of the soul in accord with virtue, and indeed with the best and most complete virtue, if there are more virtues than one". The virtues, according to Aristotle, are: courage, temperance, magnanimity, liberality, magnificence, and first and foremost, justice, which contains all other virtues, the most virtuous of which he considers distributive justice, which recalls the spirit of the Law (Kauder 1953).

In his Nicomachean Ethics, Aristotle evaluates the value of goods according to their exchange and its measure. The search for a common standard of measurement becomes part of the wider problem concerning justice and equality among men in society. In his words, "without exchange there would be no society, and without equality no exchange, and without commensurability no equality".

However, one does not always obtain commutative justice and an equivalence of exchange from this transaction, because the art of producing wealth for its own sake (in today's parlance, speculation) means the market is socially unjust and does not make men happy (instead, Eudaimonia, translated as happiness, is understood as being the highest human $\operatorname{good}^{4}$ ).

In this logic, happiness possesses a relational quality which involves man and his fellows in the context of a society. It is the essential purpose of human relationships.

These passages hold a criticism which Catholic economics still makes against capitalism (Liguori 1907 and Segre 2006): this system contains neither distributive nor commutative justice, instead displaying a speculative, individualistic approach aimed not at the common good, but at profit in itself $f^{5}$.

\footnotetext{
${ }^{3}$ Nicomachean Ethics, 5, 1133/b/18-20.

${ }^{4}$ ID., Nic. Ethics, VI, 1139/b/3

${ }^{5}$ According to this approach, he who produces goods for the purpose of accumulating wealth does so in order to hoard it or to spend it on material pleasures, neither of which lead to happiness: hoarding wealth implies never having enough of it; spending it on material pleasures, which are never-ending, implies there will never be enough money to satisfy one's desire for them. This creates a situation in which the production of goods does not lead to happiness (oriented towards equilibrium).
} 
As is well-known, in Franciscan (economic) thinking first, and then in Thomas Aquinas, the main theme is the existence of human indigence and poverty (material and spiritual) as proof of social injustice and the unequal distribution of the common good, and these concepts actually hail from Aristotelian philosophy.

Approaching Aristotle through Faith, we discover that Christianity aims to give men a new vision of collective life: true wealth comes from being generous to others. Therefore, wealth is no longer an exclusively material concept but, as it is dependent on spirituality and the sharing of the common good, is also and most importantly immaterial (Quaglioni, Todeschini and Varanini 2005).

Unlike Lutheranism, Catholicism preaches that man can achieve redemption from original sin by dedicating himself to work and good causes (as observed in the philosophy of the Franciscans). Therefore, man is a positive resource of Creation who must adopt benevolent, charitable behaviours in order to be forgiven and reach the Kingdom of Heaven.

During the XV century, thanks to the effort of Thomas Aquinas, Aristotelian thought will also influence the Spanish School of Salamanca (Zanotto 2005), whose theologians stand out for their attempt to harmonise faith with reason (as taught by Aristotle) and social reality by suggesting that governments adhere to rigorous ethical standards ${ }^{6}$.

The members of the School of Salamanca, active in XVI century Spain, were part of the revival of scholasticism, though they brought to it considerable input from the works of Aristotle and Thomas Aquinas.

It is not possible to think of the Salamanca authors as economists; they are, first and foremost, moralists who tackle problems of an economic nature in the light of their moral beliefs. In their comprehensive system of thought, the economy and its challenges was simply a part of human conscience, and as such was included in their ethical reasoning (Font de Villanueva 2010).

The founder of the School is considered to be Francisco de Vitoria O.P. (circa 1483 - 1546), who conducted important intellectual and pedagogical work, first at the Sorbonne and, from 1522 to 1546, at the University of Salamanca. A return to the source of Christian belief (the Holy Scriptures) constituted an initial acceptance of the new cultural form which was taking shape in Mediterranean Europe and the problems of mankind (religious, ethical and political) that had arisen after the discovery of new worlds in the West and the East. The sacrosanct dignity accorded to each person and the universal reach of international law (ius gentium) are included in theology and bathed in the light of Christian revelation.

The main theme tackled by the Salamanca scholars is the discussion of ethical and normative dimensions in socio-economic structures (Melè 1999 and Elegido 2009). In his History of Economic Analysis (1954), J. A. Schumpeter asserts that Italian and Spanish Franciscan scholastics were responsible for theorizing the role of the social entrepreneur in the free market.

Without a doubt, the influence of the School of Salamanca can be felt in other countries, too, owing to the fact that several of its members taught in universities

\footnotetext{
${ }^{6}$ An in-depth study of the School of Salamanca is attributed to M.G. Hutchinson, who studied under F.A. Hayek. This study traces the origins of free-market economy to Spanish Catholic Scholastic thought.
} 
outside Spain. It is positioned in the wider context of the Spanish Golden Age (Siglo de Oro).

Further reflection on common aspects in Greek, Italian Catholic and the School of Salamanca which have shaped economic Mediterranean thinking are: distributive justice, the legitimacy of profit (usury), happiness and the common good.

These themes are central to MEM and the civil economy system it represents ${ }^{7}$.

Civil economy emerges during Italian Humanism within the discussion surrounding "Aristotelian reciprocity". In the $18^{\text {th }}$ century, through the Neapolitan (Genovesi, Galiani and Dragonetti) and Milanese schools (Verri, Beccaria, Romagnosi and Gioja), it becomes a subject of study in universities, focusing on the concepts of "public happiness" and "distributive justice". Concepts which call for a vision of the economy that is collective, not individualistic, as well as a State which looks kindly on those who do not benefit from market results (Zamagni 2012).

Stefano Zamagni (1996) defines civil economy as the sum of activities in which neither formal coertion (the State), nor profit (the market) constitute the main principles of economic relations. In civil economy, economic legitimacy derives from reciprocity ${ }^{8}$.

The guiding principles of civil economy have been taken from Franciscan Catholicism, where man is homo reciprocans, interacting with his neighbour who is formed in the image of God. Concerning oneself with the needs of one's neighbour and cooperating to achieve the common good means working on the behalf of God and the greater good of the universe. Similarly, the state and the institutions of civil society must collaborate to achieve a conditions of subsidiarity in order to encourage the collective good through decisions which promote a welfare society.

Notwithstanding the historical and cultural importance of the principles of civil economy, from the time of Saint Francis to the present day, the influence of XIX century Positivism has helped assure its path has been discontinuous (Zanotto 2005 and Gentilucci 2017a).

However, Scholastic thought had already come under threat in the 16th century during Luther's Protestant Reformation and the emergence of commercial capitalism (Mercantilism). This push towards the classical individualist tradition was responsible for a cultural renewal in Europe. The Italian humanists, however, did not accept this in its entirety because they were open to the spirit of the Renaissance, against an oligarchic Europe that had a passive, sombre idea of the economy (Rothbard 1995, 194-6).

\footnotetext{
${ }^{7}$ For a more in-depth study of Civil economics see: Gentilucci $2017 \mathrm{~b}$.

${ }^{8}$ Understood as a behavioural norm (both co-operational and relational) that takes into account social, educational and human motivations that encourage economic stakeholders to enter into relationships. Reciprocity exceeds family ties, economic relations and fraternal ties: it is a responsibility towards others which stems from our shared place of origin in Creation. One consequence of reciprocal behaviour is an attention to market results that are geared towards social equity, one of the founding values of civil economics (Bazzichi 2003 and 2008). Currently the main supporters of civil economics in Italy are Stefano Zamagni and Luigino Bruni.
} 
It is, however, clear that a duality in economic thought could already be observed in XVI century Europe: on the one hand, the Mediterranean countries, influenced by Aristotelian ethical principles and the notion of distributive justice, and reciprocity and solidarity of the Catholic tradition; on the other hand, the Northern countries, marked by oligarchy and Lutheran obscurantism.

Two views of the world which, as we will see, have dictated two ways of interpreting economic relations and their purpose up to this very day.

A structural duality between Mediterranean and Continental Europe can also be observed in the economic history of the late 1800s due to the industrialisation of the latter in relation to the former.

This situation has evident sociological and cultural implications. First of all, southern Europe reached high employment in the service sector well before the high levels of industrial occupation typical of continental Europe and especially Germany (Wolleb 1993).

Thus, the common element linking Greece, Italy and Spain is a rapid growth due to the transition from an agrarian society to a tertiary (or service) economy, ensuring the pervasive presence of the State in the market. This has created at least three ways in which they differed from continental countries.

The first being that the prominent presence of the State in the market has formed a patronage-oriented society that veers towards common values that have an affinity with a particular social status. Lockwood (1992) claims that one consequence of this status-based society is the development of high levels of harmonious integration and conflict-free interactions between social groups (in contrast with the situation in so-called industrialized countries, which prioritise individualistic behaviour aimed at higher personal gain).

Second, the market influence of the State through social policie has slowed the influence of Neoclassical efficiency.

And finally, the presence of a structured agrarian society with its shared values, handed down in traditions and family ties, has incentivised the birth of a culture oriented towards collaboration, cooperation and solidarity. These values are less present in continental Europe, where society was mainly industrial in nature ${ }^{9}$.

In Mediterranean countries, the advent of democracy in the 1960s coincided with the birth of social democracy, favouring the development of a society that was diverse, more exposed to economic trends, and less geared towards production.

In turn, the fragile social structure increased the need to treat the welfare society as if it were a common good. In this sense, uniting the European market seems far more difficult for southern than continental European countries, whose

\footnotetext{
${ }^{9}$ Not forgetting the role played by the Catholic Church in the twentieth century with the publication of its social encyclicals. These documents praised the social and economic value of the family and ethics in social development. In 1891, the first Social Encyclical, Rerum Novarum, paved the way for a 10-yearly production which has continued until the most recent, Laudato Sì (2015) by Pope Francis, particularly attentive to the environmental challenges we are facing. Ethical and moral values in these letters are found in the Compendium of the Social Doctrine of the Church, published by the Pontifical Council for Justice and Peace (2004), which is deeply attentive to safeguarding employment, welfare within the social sector and the development of human resources (Gentilucci 2016).
} 
representatives have taken on the role of regulators and guardians of the markets and industrial production.

In this regard, Latouche (2000) also recognises a Mediterranean tendency to take into account the complexity of socio-economic relations, the diversity of production and ethical and social values. In particular public expenditure in MEMs is based on a low level of social assistance, free higher education, strong labour protection and welfare programs in areas such as the development of human resources.

Shifting the focus from state to market, the adoption of restrictive EU policy has obliged southern European countries to make cuts to social spending, forcing the private sector to intervene in an effort to fill the gap left by the state through the efforts of third-sector organisations (Offe 1984).

In the literature it is a well-known fact that in Mediterranean countries the non-profit sector is increasing its involvement with the profit system, in accordance with the needs of environmental and social sustainability, human rights and employment (Schneider, Schneider and Hansen 1972).

Another factor that impacted Mediterranean cultures and economies in the Twentieth century was the emigration of the workforce (skilled and unskilled workers) who left southern Europe for continental capitalist countries. Migration (emigration up to the 1960s, immigration until the 1980s) has served as instrument of social mobilisation, most of all due to the fact that income has caused a change in lifestyles, with a marked shift from an agrarian to a consumer society.

Once again, in the mid Nineties, wealth and well-being improved, but this was not accompanied by a process of capitalistic industrialisation. Instead, local traditions were invigorated, reciprocity between social groups was maintained, the political and social status was confirmed ${ }^{10}$.

A social, democratic citizenry has established itself in Mediterranean Europe, with a majority of the middle-class (artisans and state workers) and poor classes (agricultural sector) exhibiting a high degree of heterogeneity which is not found in the rest of Europe.

The welfare state is, therefore, more aid-oriented, as it is inspired by social solidarity, the redistribution of wealth and the need to support demand in order to uphold security and protect social democracy.

These characteristics clash with the principles imposed by continental monetarism (inspired by meritocracy). In substance, the hardships brought by the process of uniting the European market become even more serious in the southern European context as they express the values of an economy which (in the absence of a technocratic state, a strong industry and privatization) can only grow if demand is maintained (Sapelli 1996, p. 34-36).

Currently, MEM can be explained as a civil approach to economics which unites the Mediterranean countries and endorses an idea of the market as "anthropic and altruistic" (in the sense of a market that concerns man) in which

\footnotetext{
${ }^{10}$ Sapelli (1996, p. 30-33) highlights the fact that the process of modernization and economic integration for Greece, Spain, and Italy in an international context happened at different times but nonetheless had a common element: the fact that all these countries had experience emigration meant they were open to social integration.
} 
the state, having recognised its central role in economic growth, leaves space for civil society (the third sector). Achieving a degree of welfare that is efficient for the requirements of society is a prerogative for the state.

According to Zamagni (1997), civil economy is understood as being: "all those processes/activities for which neither formal coercion [public economy] nor the push for profit [private economy] are guiding principles [as this is given by] the principle of reciprocity".

There is a red line running from Mediterranean economic culture to the values of social cohesion.

Mainly in Italy, this deterioration has taken the form of family lobbies (clientelism) (Pridham 1984) and left no room for meritocracy ${ }^{11}$ and created a weak, inadequate managing class of policy makers, though it has also created a substrate of shared public spirit and social relations which, today, is presenting itself as an opportunity to recover from the crisis.

\section{The Historical Roots of European Social Market Economy}

The origins of Social market economy can be found in Ordoliberalism (the Freiburg School), a liberal socioeconomic model that originated in 1930s Germany in response to the deep economic and political crisis the country was undergoing.

Furthermore, the roots of Ordoliberalism ${ }^{12}$ can be traced to the Lutheran reform (the Reformation), a process in which two distinct cultures clashed: the Latin (culture), ancient in origin but subsequently refined by the Renaissance and the Catholic age (Scotti 1839); and the Germanic, coarser and cruel (Fanfani 1961, 508).

The Lutheran dynasty reached its highest form of expression with the May Laws (1873), which removed almost any form of power from the bishops (Valente 2004, 179). XIII century German culture possessed these characteristics because it had not experienced religious dominance (Weber 1965 (2002), 88). Even during the Kulturkampf struggle under the guidance of Bismarck, feelings of hostility towards the Church had not disappeared.

Lutheran capitalism derives from Martin Luther's vision of the human condition, in which man, guilty of original sin, can only find salvation by living a life of conscious repentance, at the end of which only God can grant him eternal salvation.

This pessimistic view influences human life with an eternal inner struggle: seesawing between individualism and selfishness in the hope of being forgiven at

\footnotetext{
${ }^{11}$ Meritocracy gives value to excellence irrespective of provenance, where by "provenance" we mean ethnicity, political party, gender; in Italy, though, it mainly indicates the family of origin (Abravanel 2008).

${ }^{12}$ We have to thank A. Muller-Armack for coining the phrase Social Market Economy (Soziale Marktwirtschaft). With this formula, he intended to link, on the basis of the economics of competition, free initiative to social progress through the activities of market economy (Forte Felice 2010). Muller-Armack is a member of the Freiburg School (1940), which supports a socioeconomic model that is a third way between liberalism and collectivism, maintaining that free competition must be regulated within an institutional framework.
} 
the moment of passage from earthly life. Subsequently, all contacts with other men are influenced by the fact that each one of us will focus solely on our own goals in order to obtain the best results, proving to God that we are better than the others. Luther recognised that in this world, the State must wield significant power in order to stop the freedoms of individual conscience from rendering any form of coexistence possible.

In an economic sense, this view of God exalts individualism and competition between men; it is but a short step from the religious to the social sphere. Individualism and the search for efficiency in results is also promoted (Felice 2013). Socially speaking, any action based on value judgements (such as justice and fairness) is not taken into consideration: in front of God, no man can judge whether a thing is good or bad.

We can observe a clear connection with the concept of happiness that characterises the Mediterranean view of economics. From the Lutheran perspective, man aimed not for contentment inspired by Nicomachean virtues but a Benthamian utilitarianism in which man aims to reach a state of happiness that is rational, devoid of pain, unease and dissatisfaction (absence of utility) and in which he seeks nothing less than the highest utility for himself. It goes without saying that man acts without involving his inner spirit, in a mechanistic line of reasoning that weighs up costs and benefits.

According to the outdated Weberian history of economic thought, capitalism emerged from the protestant, Lutheran tradition, while it is established that, thanks to the Aristotelian concept of liberal virtues and the notion of commerce as cumpetere (from the Latin: asking together in the market), the origin of capitalism can actually be found in Catholicism (Stark 2019).

German Ordoliberalism is a complex economic and institutional system of thought of Franciscan Lutheran inspiration which should be considered together with the bulk of the policies inspired by the members of the Freiburg School, active between the 1940s and 50s.

Its members belong to that generation of Germans who lived through the violent breakdown of their world and, more generally speaking, the death of Old Europe.

They can easily be included among those thinkers for whom the "crisis" of their era was a heavy burden to bear. For this reason, they felt a need to understand the political and economic processes that were responsible for changing the face of Europe (and the entire world) after the Great War. The economists of this particular School envisaged an economic rationale able to cancel, or at the very least to neutralise, the irrational part of capitalism through an established legal order known to us as Ordoliberalism.

The Freiburg School came to life in the cultural environment that flourished in the post-Weimar era. Its thinking was inspired by the writings of Von Mises in his 1919 paper, "Nation, State and Economy", in which it is claimed that free trade is not spontaneous but should be induced and regulated within an institutional framework.

Forte and Felice (2010) recall that the first ever systematization of Ordoliberalism would be published in Germany in 1936: "The Ordo Manifesto of 
$1936^{\prime 13}$, an interdisciplinary work combining economics and law, written by F. Böhm, H. Grossmann-Dörth and Walter Eucken ${ }^{14}$.

In 1943, at the behest of Pastor Dietrich Bonhöffer, C. Dietze, W. Eucken and A. Lampe published Economic and Social Order, with the aim of identifying the moral and ethical principles which should have guided Germany (Bonini 2012, 100).

In this rationale, they defined the conceptual and legal framework which gave birth to the Constitution of the German Federal Republic between 1945 and 1947 and laid the groundwork for the country's economic rebirth.

It is in this conceptual framework that social market economy (Soziale Marktwirtschaft) was born. In 1956, A. Muller-Armack employed this market formula to connect free enterprise with social progress, on the basis of the economics of competition and guaranteed by market economy conditions (Forte and Felice 2010, 89), pointing towards a third way between liberalism and collectivism in which free competition is regulated in an institutional framework.

Finally, the debate on social market economy was concluded by Wilhelm Röpke in his 1958 paper, The Social Framework of the Free Market - A Humane Economy (Forte and Felice 2010, 140-42) ${ }^{15}$.

Last but not least, thanks to the contribution of W. Erhard, the social market economy was effectively brought to and applied in Europe from the 1950s onward.

As already mentioned, Ordoliberalism emerges from a historical and cultural context of Lutheran inspiration, and its theorists, though Protestant, were inspired by Christianity, there existed a profound difference between their concept of market economy and the doctrine accepted by the Church. The market was seen as a place where solidarity was considered as being above other criteria for action in the market economy.

However, the Ordoliberals conceived of the market as being regulated on the basis of selfish interests in which each actor tries to maximise his utility and competitive advantages. Though this position is certainly close to Anglo-Saxon liberalism, we must point out an important difference between the two: liberalism tends to distrust state intervention, viewed as inappropriate as market laws guarantee competitive relationships and the best allocation of resources; instead, Ordoliberalism supports the idea that when a market is left to its own devices, power will become concentrated into few offices, favouring inequality and lack of social justice and jeopardising freedom of enterprise (Joerges 1997) ${ }^{16}$.

\footnotetext{
${ }^{13}$ The ordoliberal model is at the root of the current incarnation of the European Union (Forte and Felice 2010, 8).

${ }^{14}$ The latter also published, in 1939, I fondamenti dell'economia politica, reprinted 1951, Sansoni Firenze.

${ }^{15}$ Also: W. Röpke "Presupposti e limiti del mercato" from the volume Al di là dell'offerta e della domanda. Verso una economia umana (1958); and "Teoria degli interventi conformi", La crisi sociale del nostro tempo.

${ }^{16}$ See: A. Musto (2011), "Economia sociale di mercato e trattato di Lisbona. Sintesi critica di un seminario fiorentino", Persona e Mercato Saggi, http://www.personaemercato.it/wp-content/uplo ads/2011/10/musto-attualita.pdf
} 
Consequently, to correct the interests of society, prevent sectoral agreements and monopolistic practices and guide market action towards a pure, orderly form of liberalism, the state is required to be strong. Its role is to protect market mechanisms, not existing enterprises (Libertini 2009).

However, this method will only allow the strongest companies to survive competition, and leave very little room for companies with low profit margins, such as small enterprises or non-profit establishments which are very common in Mediterranean countries.

For these reasons, social market economy is also known as an "economy of rules" and is the place where economics and the law meet and give birth to an "economic constitution", untouched by any form of economic planning or state intervention ${ }^{17}$.

In this approach, competition is recognised as a public good and a harbinger of liberal principles that, like other constitutional principles, must be protected: the State, therefore, takes on the role of arbiter of market rules.

The basic qualifying points of social market economy can be synthesised in this way: a stringent monetary regime; credit given in compliance with the rules of competition; the regulation of competition to avoid the risk of monopolies; a neutral fiscal policy in relation to competition; avoiding subsidization which might alter competition; environmental protection.

\section{The Difficulties faced by Europe}

Within the context of the current debate surrounding the European Union, one of the burning issues concerns the degree to which Ordoliberal principles can be held accountable for the position Germany has assumed regarding imbalances within the Eurozone.

According to Mesini (2018), they are directly responsible for the current situation, seeing as constraints imposed by Ordoliberal thought have become the main driving force in the European economic union. This claim is supported by the position assumed by Germany on bailout policies for the crisis-hit countries which do not follow Ordoliberal principles ${ }^{18}$. After all, as stipulated in the Treaty of Lisbon (2008) under art.3 comma 3:

The Union shall establish an internal market. It shall work for the sustainable development of Europe based on balanced economic growth and price stability, a highly competitive social market economy, aiming at full employment and social

\footnotetext{
${ }^{17}$ More recently, the Austrian School of Von Mises seems to have tackled the subjects dear to social market economy through the contributions of Thomas Woods, Wilhelm Roscher and Joseph Novak. Goldschmidt defines Ordoliberalism as a mélange of socio-political ideas favouring a free, socially just society which defines some general rules of economic policy. A decidedly liberal concept, founded on individual freedom and the conviction that functioning markets and competition lead inevitably to economic efficiency (Felice 2008).

${ }^{18}$ Such as the reluctance with which Germany participated in the European Stability Mechanism, set up in 2012 to provide loans to euro area countries in financial distress (Greece, Cyprus, Portugal, Ireland, Spain) which is being hotly debated in Europe.
} 
progress, and a high level of protection and improvement of the quality of the environment. (Musto 2011)

In our opinion (and that of an extensive collection of literature), the phrase "highly competitive social market economy" points to the applicability of Ordoliberal principles in all European countries, even the Mediterranean group who share the economic history of Germany and have found, as we shall see, difficulty in following the requirements of a monetary stability that is leading Europe towards a gloomy austerity.

A further remark appears to be relevant. In the Treaty of Amsterdam (1999), the first fundamental document establishing the Union, art.4 clearly identifies "free competition" as one of the fundamental values of EU law. The fact that this term has been replaced by "competition"19 should not be underestimated, as it indicates a change of strategy on the part of the political institutions in their management of economic relations within the Union. According to some, this was a legislative political decision, aimed at redefining the set of values embraced by Europe (De Pasquale 2009, 81).

Competition implies antagonism, such as we may find in a sports competition; rivalry and the struggle for an exclusive result (in the sense that it excludes other participants); instead, free competition implies the existence of a market in which individuals are free to express their choices in function of their ethical motives, a place where economic relations can be regulated by reciprocity and an acknowledgement of shared values (Corso 2006).

In agreement with the views expressed by Zamagni and Bruni (2009), MEM economies see competition as lower on the value scale compared to free competition.

In this approach, social and solidarity policies beneficial to civil society, but not directly aimed the production, are excluded from the market. Consequently, any contribution from the third sector is tolerated, but not relevant to the agenda for economic policy. The state must safeguard an efficient, competitive environment.

Furthermore, as evidenced by large numbers of Italian, Spanish ${ }^{20}$ and Greek economists (Varoufakis 2018) ${ }^{21}$, Germany has improved its economic performance (also shown by its constant trade surplus) while countries like Greece, Portugal, Spain, Italy and France have found themselves accumulating increasing debt, creating a situation which has aggravated their National economic difficulties without allowing them to overcome their structural imbalances.

\section{Which way forward for Europe}

We shall start with a quote from J. M. Keynes (1926):

\footnotetext{
${ }^{19}$ In the Italian language, concorrenza, or "free competition", is understood to be a type of competition in which participants compete jointly to reach a result that is satisfactory for all; while competizione, or "competition", implies participants are rivals or antagonists.

${ }^{20} \mathrm{~A}$ document addressed to the Institutions of the European Union which was signed by a few hundred Italian and Spanish economists http://www.letteradeglieconomisti.it.

${ }^{21}$ See also: Laskos and Tsakalotos (2015).
} 
The political problem of mankind is to combine three things: economic efficiency, social justice and individual liberty. The first needs criticism, precaution and technical knowledge; the second, an unselfish and enthusiastic spirit which loves the ordinary man; the third, tolerance, breadth, appreciation of the excellencies of variety and independence.

The first point to make on the subject is that, as is widely known, Keynes was both witness and analyst of a market system which was very similar to the current Mediterranean Economic Model: characterised by an underemployment equilibrium, guaranteed by insufficient demand (with a persistent shortfall) and weak social (welfare) guarantees. In this context, following Keynes' logic, the state is entitled to invest in socially beneficial areas that are often neglected by private investors, due to them not being profitable enough. In this way, the state stimulates aggregate demand and helps the weaker sectors of the population, unlike the free market guaranteeing adequate levels of social justice.

The quote by Keynes leads us to yet another consideration: the economic systems analysed in this paper appear to regard efficiency, individual freedom and social justice in a different manner.

In Social Market Economy, economic freedom leads to efficiency (imposed by price as a measure of scarcity), and the latter becomes an expression of a social justice which does not impose value judgement (the results of an efficient market are the best for the community).

In MEM, social justice is the expression of a welfare society that is attentive to the common good and therefore the efficacy of its action, it guarantees individual freedoms without harming economic efficiency. Indeed, in this model, the market and the state are not antagonists, but subsidiary to each other.

It is, furthermore, interesting to note that the Freiburg School of old (Röpke 1963), and the contemporary ESM system are opposed to Keynesian thinking (Felice 2007; Forte et al. 2013) as public spending leads to inflation (due to deficit financing), even though it is very unlikely that applying a restrictive monetary policy will create employment and boost demand (unless we appeal to Say's Law which, however, does not seem to have ever amounted to anything in the history of capitalism).

In truth, Keynes' vision still seems to suggest the best solution for the current crisis in the European system, since in an under-employment equilibrium, deficit spending would boost the inner wheels of the income multiplier without producing inflation.

It must also be remembered that when Keynesian policies were applied to capitalist economies in the 1960s, their budget deficit never exceeded 1\%; and that when, in the 1970s, Keynesian economies fell out of favour in the academic mainstream in favour of Friedman's theory of monetarism, budgetary deficits rose to over $4 \%$ until the 1980s (Conti 2015).

Today, just as then, the problem facing the MEM countries does not seem to be the threat of the return of inflation (the current trend favours deflation), rather high unemployment coupled with the lack of adequate levels of aggregate demand, before even considering the fact that cuts to the welfare state bring about a situation of collective unease which magnifies problems (Atkinson 2000). 
In Mediterranean economic thinking, an efficient management of public spending, attentive to efficacy and collective needs, would contribute to growth without inflation even in a situation of deficit, especially if it was open to innovative investment in areas that are not traditionally favoured by the for-profit sector (Varoufakis 2018).

The continental countries (Germany and France), being based around traditional industry and a trade surplus, have the opposite problem: they must rein in demand and public spending to ensure the stability of the euro.

In short, we would like to cast doubt on two stereotypes: that European concerns regarding Ordoliberal monetary policy are wrong, and budget deficits are always connected to welfare society choices that aim to boost demand.

\section{The Future of MEM in Europe}

There is therefore a clear fact: in Europe, there are two distinct economic macrosystems with their own history, philosophy and cultural traditions. These cannot be placed together under the same economic logic: just as monetarism has shown how devastating it is for Mediterranean countries, in the same way Keynesian policies would be inappropriate for the fundamentals of continental Europe.

In our opinion, the Eurozone's general malaise can be traced to these differences, which are cultural and structural in nature.

Culturally, each economic system comes into being and develops following a personal historical path: in other words, an economic system is similar to a piece of clothing which fits the wearer, but will be a bad fit for those who don't possess the same characteristics.

Thus, if ESM is a historical phenomenon limited to the German Federal Republic which, from 1949 to 1966 was responsible for the Ordoliberal-inspired economic miracle of the 1950s; MEM, on the other hand, is inspired by a farreaching millennial thinking which has forged cultures and traditions from Aristotle to the present day and has as its focus the welfare society (Mesini 2018).

Consequently, even structurally speaking there are actually two methods of managing the market: the German ESM based on a liberal state, arbiter of an industrialised production system; and a Mediterranean system based on a subsidiary collaboration between state institutions and civil society to implement policies of welfare society.

So is there a common road to growth in Europe?

The problem brings us back to the unsolved dilemma of whether it is possible to export pre-existing market models. The fact that it seems impossible to solve this dilemma is down to differences in the economic and social makeup of the southern European countries. It is difficult to reconcile their public and private institutions with monetarist policies, though they find a more favourable environment in welfare society policies.

In order to support the union of Europe, a new vision and new direction for general economic policy is needed.

Accordingly, Ingellis (2017) wrote: 
Both in the European political debate and in the mass media representation of the downturn impact, Italy, Portugal, Greece and Spain are considered the countries with the worst situation up to the point of being called "PIGS", in a derogative sense.

The question to ask is not, therefore, whether MEM countries should be called "PIGS", but whether Keynesian policies should always be considered harmful; or if, on the other hand, blockages to growth might not be brought about by the practice of applying monetary policies indistinctly to all socio-political conditions.

It is not easy to identify a common path to growth for Europe; perhaps, instead of trying to standardise differences and in the process distorting their identity, it might be more appropriate to embrace this diversity as offering opportunities for growth and the protection of human rights and economic liberalism: the PIGS could be taken as an example of the power of solidarity and the welfare society to make the human-centred market more efficient. Likewise, the countries of northern Europe could remain an example of constitutional economic liberalism which guarantees the existence of efficient markets in the absence of power positions.

Furthermore, in close co-ordination with the monetary policy imposed by the European economic system (as per the social market economy), it is necessary to suggest surplus countries take measures to increase demand in order to start a process of sustainable rebalancing vis-à-vis the non-euro area.

\section{Conclusion}

Therefore, MEM offers a view of capitalism which brings the countries of Mediterranean Europe together: with its roots in the philosophy of Aristotle and St. Thomas Aquinas, flourishing in Italian humanism and the Spanish School of Salamanca and finding its identity in the current system of civil economy. The shared historical origins of Mediterranean thought are also a sign of a common economic vision which is attentive to the welfare society and collective needs. However, these characteristics also seem to be at the root of difficulties which are faced on the path towards the monetary union dictated by Germany.

In fact, the European economic model has been shaped by social market economy Ordoliberal principles founded on an austere, Lutheran concept of the welfare state, where the state is a neutral figure, guarantor of market competition.

The fact that European institutions have failed to take into account cultural differences between MEM and ESM is the chief cause of challenges faced by Mediterranean countries which are trying to maintain their position within the European Union. There is much literature confirming that Keynesian policies, albeit denied by restrictive monetary policy, would give them room to breathe ${ }^{22}$.

\footnotetext{
${ }^{22}$ Ironically, some American economists have described this particular European policy choice as the "Pact of Stupidity" seeing as the practice of curbing public spending and applying restrictive monetary policies tends to lead to recession instead of supporting growth. Essentials of Economics, Krugman et al. (2016).
} 
In reality, the evident difference between Mediterranean and continental Europe regarding the management of public spending should not be analysed here, though it should make us reflect on the fact that historical processes should never be underestimated.

To sum up, it is necessary for Europe to embark on a path which focuses on the following areas: on the development of productive forces, of increasing wellbeing, protecting the environment and territory and social equity. It is possible to carry such a task out in line with monetary stability, whilst taking into account liberal culture and the requirements of civil society which plays such an important in the MEM countries.

\section{References}

Abravanel R (2008) Meritocrazia. Garzanti.

Atkinson AB (2000) Welfare state. Le conseguenze economiche dei tagli allo Stato sociale. Milano Etas.

Bazzichi O (2003) Alle radici del capitalismo. Medioevo e scienza economica. Effatà Editrice.

Bazzichi O (2008) Dall'usura al giusto profitto. L'etica economica della Scuola francescana. Effatà Editrice.

Bonini L (2012) Economia sociale di mercato. Edizioni Studio Domenicano.

Bruni L, Zamagni S (2009). Dizionario di Economia Civile. Voce "Concorrenza", Edizioni Città Nuova.

Conti $\mathrm{G}$ (2015) Le due terze vie: la regolamentazione macro e micro economica del capitalismo. Una riflessione. Discussion Paper/195.

Corso G (2006) La tutela della concorrenza. In Il diritto amministrativo dopo le riforme costituzionali. Corso, G. and Lopilato, V. Ed. Giuffrè Editore.

De Pasquale P (2009) Libera concorrenza ed economia sociale di mercato nel Trattato di Lisbona. In Diritto pubblico comparato europeo. 81.

Elegido JM (2009). The Just Price: Three Insights from the Salamanca School. In Journal of Business Ethics. November.

Fanfani A (1961) Storia economica. Antichi.ta', Medioevo, Eta' moderna. UTET.

Felice F (2007) Welfare society. Dal paternalismo di Stato alla sussidiarietà orizzontale. Soveria Mannelli Rubettino.

Font de Villanueva C (2010) The School of Salamanca: somethought on the subject of justice. In Human and Religion in the History of Economic Thought. Parisi, D. and Solari, S. Ed. Franco Angeli.

Forte F, Felice F (2010) Il liberalismo delle regole. Genesi ed eredità dell'economia sociale di mercato. Rubbettino.

Forte F, Felice F, Forte C (2013) L'economia sociale di mercato e i suoi nemici, Soveria Mannelli, Rubettino.

Fortis M, Quadrio Curzio A (2007) Valorizzare un'economia forte. Il ruolo della sussidiarietà. In Economia Politica. No. 3:477-483.

Gentilucci CE (2017a) L'Europa tra vocazione mediterranea e capitalismo luterano. In L'Italia centrale tra Medioevo e contemporaneità. Di Stefano E. and Gentilucci C.E. Ed. Regione Marche.

Gentilucci CE (2017b) L' Economia Civile e l'Economia Sociale di Mercato. In Studi Economici e Sociali. 
Gentilucci CE (2018) Mediterranean civil economy and the European system. In Science \& Philosophy. Vol. 6 n. 1

Gosta Esping A (1990) The Three Worlds of Welfare Capitalism. Priceton University Press, New Jersey.

Ingellis AG (2017) The Impact of the Crisis on Economy and Labour Market in the Southern European Countries. What about the "Mediterranean Model"?. In Athens Journal of Social Sciences. No. 4 (3: 249-264).

Joerges C (1997) The market without the State? The economic constitution of the European community and the rebirth of the regulatory politics. In European Integrations. No. 1 (17).

Kauder E (1953) Genesis of the Marginal Utility Theory: From Aristotle to the End of the Eighteenth Century. In The Economic Journal. Vol. 63 (251:638-650).

Keynes JM (1926) La fine del laissez faire e altri scritti economici e politici. Bollati Boringhieri.

Krugman P, Wells R, Graddy K (2016). Essentials of Economics. Worth Publishers

Laskos C, Tsakalotos E (2015) Crucible of Resistance, Greece, the Eurozone and the World Economy. Palgrave Macmillan.

Latouche S (2000) La sfida di Minerva. Razionalità occidentale e ragione mediterranea. Bollati Boringhieri.

Libertini M (2009) Clausola generale e disposizioni particolari nella disciplina delle pratiche scorrette. In Contratto e Impresa. No. 73/09.

Liguori A (1907) Theologia Moralis. Roma.

Lockwood D (1992) Solidarity and Schism. The problem of Disorder. In Durkheimian and Marxist Sociology, Clarendon Press.

Melè D (1999) Business Ethics in Spain: The Salamanca School (1526-1614). In Journal of Business Ethics. Nov. 22/3:175-189.

Mesini L (2018) L'ordoliberalismo trionfo e crisi dell'ideologia tedesca. In Limes. No. 12.

Musto A (2011). Economia sociale di mercato e trattato di Lisbona. In Persona e Mercato. http://www.personaemercato.it.pdf.

Offe C (1984) Contradictions of the Welfare State, Hutchinson.

Pridham G (1984) The new Mediterranean Democracies. Regime Transition in Spain, Greece and Portugal. Frank Cass.

Quaglioni D, Todeschini G, Varanini G (2005) Credito e usura fra teologia, diritto e amministrazione. Collection de l'École Française de Rome.

Ropke W (1963. Economics of the Free Society. Henry Regnery Company.

Rothbard MN (1995) Economic Thought Before Adam Smith. Elgar Pubblishing.

Sapelli G (1996) L'Europa del Sud dopo il 1945. Rubbettino.

Schneider P, Schneider Y, Hansen E (1972) Modernization and Development. The Role of Regional Elites and Noncorporate Groups in the European Mediterranean. In Corporative Studies in Society and History. No.14: 320-50.

Scotti A (1839) Teoremi di politica cristiana. Mendrisio Tipografia Ticinese.

Segre S (2006) Il profitto capovolto: epistemologia del non profit. In Rivista di diritto finanziario e scienza delle finanze. No. 4.

Stark R (2019) The Triumph of Christianity: How the Jesus Movement Became the World's Largest Religion. Lindau.

Varoufakis Y (2018) Austerity: Vintage Minis. Kindle Editions.

Vryonis S (1978) The Past in Medieval and Modern Greek Culture. Undena Publications.

Weber M (1965) The sociology of religion. London Methuen.

Wolleb G (1993) Sviluppo economico e squilibri territoriali nel sud Europa. Il Mulino.

Woods E (2005) The Church and the Market. A Catholic Defense of the Free Economy. Lexington Books, Lanham. 
Zamagni S (1996) Se si afferma l'economia civile. In Impresa Sociale. No. 29.

Zamagni S (2012) Felicità pubblica. In Il contributo italiano alla storia del pensiero economico. Treccani.

Zanotto P (2005) Cattolicesimo, protestantesimo e capitalismo. Dottrina Cristiana ed etica del lavoro. Rubbettino. 
